\title{
Target for Intervention in At-Risk Children
}

Bruce E. Wexler ${ }^{1 *}$, Ahmet Esat Imal ${ }^{2}$, Brian Pittman ${ }^{3}$, Morris D. Bell ${ }^{3}$

${ }^{1}$ Department of Psychiatry and the Connecticut Mental Health Center, Yale

University, New Haven, CT, USA

${ }^{2}$ Department of Psychiatry, Yale University, New Haven, CT, USA

${ }^{3}$ Department of Psychiatry and the West Haven VA Medical Center, Yale University,

New Haven, CT, USA

\section{ABSTRACT}

Aim: Determine whether effects of poverty on academic achievement are mediated by effects of poverty on executive cognitive functions. Methods: Web-based classroom-administered tests assessed executive function in 5717 children grades k-8 in 40 schools, and poverty level and academic achievement for each school were drawn from US Department of Education data. Boot-strapping procedures were used to evaluate mediation by executive function of the association between poverty and academic proficiency. Results: Executive function and academic achievement were both related to school poverty (pearson $r-0.50$ to $-0.65, p=0.0009$ to $<0.0001)$. Estimated indirect effects of poverty on reading $(-0.26,95 \% \mathrm{CI}$ : $-0.47,-0.07)$ and math $(-0.23,95 \% \mathrm{CI}:-0.44,-0.06)$ through effects on executive function were significant. Controlling for executive function, effects of poverty on reading $(-0.58$ to -0.31$)$ and math $(-0.59$ to -0.35$)$ were diminished, indicating partial mediation of effects of poverty on reading and math via effects on executive function. Conclusion: Interventions that enhance executive function in children in impoverished and/or violent environments could mitigate damaging effects of these environments on neurocognitive and associated life and health outcomes. Without intervention, many young adults in troubled areas of the world will be ill-prepared for productive function in society.

Keywords:

Academic Achievement, Executive Function, Poverty, Violence, Neurocognitive Development

\section{Introduction}

Executive cognitive functions (EF), including attention, self-control and memory, powerfully predict a wide range of important life outcomes starting with academic success in elementary school and beyond, absence of legal problems, and multiple health outcomes. Children with stronger EF engage more effectively with classroom learning activities (Nelson et al., 2017) and have higher reading and math achievement in elementary school (Yeniad et al., 2013; Best et al., 2011; Cantin et al., 2016). A 16-year longitudinal study of $12,0003^{\text {rd }}$ grade children found that the $17 \%$ with the lowest attention skills had a $7.6 \times$ greater chance of becoming high school drop outs with the accompanying life consequences (Pingault et al., 2011). In a study following 1000 children from birth to age 32, childhood self-control predicted metabolic syndrome, respiratory disease, periodontal disease, inflammation, sexually transmitted infections, tobacco and other substance dependence, personal finances and criminal offences, controlling for effects of general intelligence and social class (Moffitt et al., 2011). 
Other research has established that children raised in impoverished communities (Noble et al., 2007; Welsh et al., 2010; Blair et al., 2011; Haft \& Hoeft, 2017; Ready \& Reid, 2019) and in communities with high levels of violence have lower EF (Heissel et al., 2018). Compromised development of brain systems associated with EF in children from these disadvantaged backgrounds has been demonstrated as early as 9 months of age (Tomalski et al., 2013) and is evident in measures of brain structure as well as function (Noble et al., 2015). Research has identified multiple mechanisms through which disadvantaged and problematic childhood rearing environments compromise development of EF, and associated brain structures with life-long consequences (Jensen et al., 2017). These mechanisms include parental stress, fatigue and anger (Luby et al., 2013), less time spent by parents talking to and reading to their children (Hammond et al., 2012), fewer resources for instructional toys and exposure to interesting places and activities, exposure to environmental toxins, poor nutrition and sleep, and exposure to violence and stress (Sharkey et al., 2012). A recent study found that children in a city in the United States slept significantly less the night after a violent crime in their neighborhood, and had elevated cortisol levels the next morning (Heissel et al., 2018). Controlled studies in animals and correlational studies in children demonstrate a link between elevated cortisol and compromised development of EF (Blair \& Raver, 2016).

These two sets of findings together strongly suggest that compromised EF is an important mechanism for the impact of poverty and violence on academic achievement, health and other important life outcomes. This has led to suggestions that because of the great individual and social costs associated with growing up in poverty and associated low EF, interventions are urgently needed to improve EF in children at risk for compromised EF development (Moffitt et al., 2011; Luby et al., 2013; Diamond \& Ling, 2016). However, direct evidence demonstrating if and to what extent EF dysfunction mediates the impact of poverty on academic and life outcomes is, in fact, sparse. In a study of $915^{\text {th }}$ grade children in poverty community schools, Waber et al. (2006) found that EF accounted for about $40 \%$ of the variance in math and reading proficiency test scores. Although this study found that variance in EF among children in poverty area schools contributes significantly to academic outcomes, the same was found among children living in affluent communities. The study was not designed to examine whether differences between children in high poverty vs. affluent communities in academic outcomes were mediated by differences in EF. In a more direct assessment of mediation in a study of 49 children (54 - 66 months old) in a small town, Dilworth-Bart et al. (2012) found that EF did significantly mediate the effects of socioeconomic status (SES) on math competency, but notes that the study was limited both by sample size and constricted range of SES, as the children were mostly from well-educated middle-income homes. The most compelling existing data of mediation by EF deficits of the effects of poverty on academic outcomes is provided by a study of the development of brain regions important in EF (Hair et al. 2015). In this longitudinal brain imaging study of 389 children including $25 \%$ from households with reported income less than $200 \%$ of federal poverty levels, $10 \%-15 \%$ of the effects of poverty on academic outcomes were accounted for by the measured effects of poverty on brain development.

The present study of a large sample of children from kindergarten to $8^{\text {th }}$ grade in schools located in a wide range of socioeconomic settings in the United States aimed to provide a more definitive test of the hypothesis that EF abilities mediate the relation between compromised rearing environments and academic achievement, and provide additional estimates of the magnitude of the mediation effect. Such data, together with existing data, would provide compelling evidence for allocating 
funds to develop and implement existing interventions to promote EF development in communities compromised by poverty and disrupted by violence (LCAH, 2019).

\section{Methods}

\subsection{Participants}

Participants were all children $(n=5717)$ grades $K-8$ in schools $(n=40)$ across the United States in which at least 20 children in a single grade used a cognitive skills training program purchased by their school from C8 Sciences and had valid on-line classroom-administered tests of EF. Individual EF data were aggregated at the school level since available socioeconomic and academic proficiency data were available only at the school level. In order to have a large enough sample to create a representative value for each school, schools were only included if there were at least 20 children in a single grade with valid assessments on all three EF tests. Since school officials selected the program for use in their curriculum and all data analysis was on the group level without identifying information on individual children, the Yale Human Investigations Committee determined that individual consent was not needed and all procedures were in accordance with the Helsinki Declaration of 1975, revised in 1983.

\subsection{School Socioeconomic Status and Academic Outcome}

The percentage of children eligible for free or reduced lunch based on family income was used as the indicator of the SES of the community of each school. Academic achievement was measured by the percentage of children meeting math and reading proficiency levels on school-administered state proficiency exams. All data were drawn from the US Department of Education, National Center for Education Studies (data available at https://www.niche.com).

\subsection{Measures of Executive Function}

EF outcomes were assessed with three web-based measures embedded in the cognitive skills training program and automatically presented, administered and scored in the classroom. EF measurements started on the third day of the program to give teachers and students time to be familiar with the program, and were given either one per day for three days or two per day for two days. Two tests (Flanker and Working Memory) followed precisely the design of tests in the NIH Toolbox of tests of EF (nihtoolbox.org). The third test is a Go/No-Go test of response inhibition, very similar to continuous performance tasks commonly used in research studies. The fact that the tests are done in the classroom environment adds ecological validity to the scores. But since the testing environment is not controlled and there are no direct observations of children while testing, test validity criteria are applied as part of the auto-scoring of all tests (see below).

The Flanker Test of focused attention uses reaction time on correct incongruent trials as its primary performance measure. In this task, children indicate by keyboard response the pointing direction (right or left) of the center arrow in a linear horizontal array of five arrows. On incongruent trials, the four "flanking" arrows point in the opposite direction of the central arrow. Following the procedure of the NIHToolbox, there are 29 congruent trials and 17 incongruent trials. Response times longer than 4500 msec on incongruent trials and $3500 \mathrm{msec}$ on congruent trials were so slow as to suggest classroom distraction or momentary disengagement from the test, and those trials were excluded. Response times faster than $150 \mathrm{msec}$ 
suggested random responding and such trials were also excluded. Tests with more than 4 incongruent "too slow" trials, more than 7 congruent "too slow" trials, more than 4 "too fast" trials, less than $75 \%$ correct on the congruent trials or fewer than 8 correct incongruent trials were considered invalid because there were not enough valid trials to reliably evaluate performance and because they suggested repeated distraction or disengagement. Finally, tests were considered invalid if average reaction time was more than two standard deviations from the mean.

The List Sorting Working Memory Test presents the child with a series of animals or household objects. The child must select the objects just seen from among a grid of 16 objects, clicking them in order from smallest to largest rather than the order in which they were presented. The test starts with a list of 2 objects. If the child completes the list accurately, list length is increased by one. If the child errs, the same length list is repeated. Two failed attempts at the same list length ends the test. The score is the sum of correct list lengths. The test has two parts. In part one, trials of animals and household objects alternate. In part two, animals and household objects are presented in the same trial, and the child must reorder the animals first and then the household objects. As a validity check, if a child was unable to report back two items in correct order, we considered it possible that the child did not understand or engage with the test and their scores were considered invalid.

The Go/No-Go Test of Response Inhibition instructs the child to press the space bar whenever a "Go" stimulus is presented but not when a "No-Go" stimulus is presented. There are three blocks with different stimuli, 50 stimuli per block with 40 Go and 10 No-Go trials, randomized in sets of 10 with 8 Go and 2 No-Go in each set. In the first block " $\mathrm{P}$ " is the Go stimulus and " $\mathrm{R}$ " is the No-Go stimulus. In the second block this is reversed. In the third block, pictures of furniture are the Go trials and pictures of foods like cake and ice cream are the No-Go stimuli. Stimuli are presented for $400 \mathrm{msec}$ with a $1400 \mathrm{msec}$ response window after stimulus offset. Errors are indicated by display of a large red "X." Trials with response times greater than $2000 \mathrm{msec}$ were eliminated since the response was after presentation of another stimulus. Trials with response times less than $150 \mathrm{msec}$. were also eliminated because response was too fast to confidently be related to the stimulus. Tests with less than $85 \%$ correct response to Go-Trials were considered invalid because the child failed to establish the consistent response bias required to measure response-inhibition. Also, not responding due to general inattention or poor accuracy artificially elevates the rate of No-Go trials correctly skipped. Tests with more than 10 "too slow" trials or more than 15 "too fast" trials were also considered invalid because of concern that the children were attending inconsistently or responding randomly.

\subsection{Statistical Analyses}

Relations among EF, school SES and school academic achievement were evaluated using average grade-based z-scores for children within each school (Figure 1). All variables were coded such that higher scores indicate better performance. Potential associations between levels of lunch subsidization, EF (Flanker, GNG, WMT), and reading and math proficiency were assessed using correlation analysis. Mediation by $\mathrm{EF}$ of the association between lunch subsidization and academic proficiency was evaluated as outlined by Baron and Kenny (1986). The
(a)
(b)
(c)

Figure 1. Age-related growth on three tests of Executive Function: Flanker Test of Focused Attention (reaction times on correct incongruent trials become faster); 
Go/No-Go Test of Response Inhibition (percent correct on No-Go trials); List Sorting Working Memory Test (total score).

estimated indirect effect was tested for significance using bootstrapping procedures (Preacher \& Hayes, 2004) with $n=5000$ samples. In lieu of testing the mediating effects of each EF measure separately, regression-based factor scores were estimated based on a one-factor solution for the Flanker, GNG, and WMT tasks. Despite its low factor loading, the GNG task was included in the calculation of the EF factor score so as to encompass all available information. Analyses were conducting using SAS, version 9.4 (Cary, NC).

\section{Results}

Growth of Executive Function: As expected, improvement in EF from $\mathrm{K}$ to $8^{\text {th }}$ grade is significant on all tests (effect of grade $p<0.0001$, Figure 1).

Relations Among EF, SES and Math and Reading Achievement (Table 1): Increased lunch subsidy was strongly associated with diminished performance on both the Flanker and WMT tasks and math and reading assessments. No associations with performance on the GNG task were observed.

Regression models (Table 2, Figure 2(a), Figure 2(b)) showed significant relations between lunch subsidization and EF $(b=-0.57, p<0.0001)$ and EF and both reading $(b=0.46, p=0.002)$ and math $(b=0.42, p=0.005)$ proficiency after controlling for lunch subsidization, supporting the mediation hypothesis. The estimated indirect effect was $(-0.57)(0.46)=-0.26$ on reading and $(-0.57)(0.42)$ $=-0.24$ on math, with both significant according to bootstrap results

Table 1. Correlations among lunch subsidization, measures of executive function, and reading and math proficiency $(n=40)$.

Lunch: \% students receiving free or reduced lunch; Flanker: (Flanker Test) reaction time to target (coded such that higher scores indicate better performance); GNG: (Go-No-Go task) correct percent; WMT: (Word Memory Test); Read: \% students reading proficient; Math: \% students math proficient.

Table 2. Summary of mediation analyses.

(a) (b)

Figure 2. (a) Regression coefficients for relations between percent of children in the school receiving free or reduced lunch and Executive Function, Executive Function and Reading Proficiency, and percent of children in the school receiving free or reduced lunch and Reading Proficiency without and with mediation by effect of percent of children in the school receiving free or reduced lunch on Executive Function. $* * * p<0.001, * * p<0.01, * p<0.05$. (b) Regression coefficients for relations between percent of children in the school receiving free or reduced lunch and Executive Function, Executive Function and Math Proficiency, and percent of children in the school receiving free or reduced lunch and Math Proficiency without and with mediation by effect of percent of children in the school receiving free or reduced lunch on Executive Function. $* * * p<0.001, * * p<0.01, * p<0.05$.

(reading: $-0.26,95 \% \mathrm{CI}:-0.47,-0.07$; math: $-0.23,95 \% \mathrm{CI}:-0.44,-0.06$ ). The effect of lunch subsidization, after controlling for EF, was significant, but diminished on both reading $(-0.58$ to -0.31$)$ and math $(-0.59$ to -0.35$)$, consistent with 
partial mediation. $46 \%$ and $40 \%$ of the effect of lunch subsidization on reading and math proficiency was mediated via EF.

\section{Discussion}

Previous research has established that EFs of focused attention, inhibition and working memory continue to develop throughout childhood, predict academic success, and are compromised in children from impoverished backgrounds. These findings have suggested that compromise in EF may be one important cause of lower academic achievement in children in poverty area schools. However, data confirming this hypothesis has been limited and some possibly even nonconfirmatory e.g., The present study provides the first confirmation in a large and economically diverse sample that EF deficits substantially mediate the impact of poverty on academic achievement. These findings, together with the studies showing impact on brain development in regions associated with $E F$, and mediation of the effects of poverty on academic achievement by alterations in brain development (Hair et al., 2015), support suggestions that childhood intervention to improve EF may have significant positive value at both individual and social levels.

"Poverty disproportionately affects the young. Worldwide, one in five children, a staggering 385 million, survive on less than US\$1.90/day (LCAH, 2019)." Of the children under the mandate of the UN Commission on refugees, nearly 3 million do not attend school (https://www.unicef.org/eca/emergencies/latest-statistics-andgraphics-refugee-and-migrant-children). Over $40 \%$ of Syrian child refugees in surrounding countries are out of school, and millions more in Syria are exposed daily to the full range of environmental factors that compromise EF (Jensen et al., 2017). Similar conditions face additional millions of children in Yemen where thousands have died from starvation, 5 million are said to face starvation and 11 million are in need of humanitarian aid according to the United Nations, in a country of only 25 million (https://www.savethechildren.net/article/yemen-further-one-millionchildren-risk-famine-food-and-fuel-prices-soar-across-country, https://www.unicef.org/mena/press-releases/three-million-children-born-waryemen). Without intervention, it is likely that large numbers of children will become young adults without the cognitive skills to function effectively in $21^{\text {st }}$ century societies, with increased medical disease ${ }^{8}$ and with the potential to burden and destabilize social organization rather than contribute to it.

These statistics portend serious risk for individual and societal well-being and stability. Current understanding of healthy brain development and the brain's neuroplastic potential provide evidence-based and targeted interventions to address this crisis (Diamond \& Ling, 2016; Jensen et al., 2017). Randomized controlled trials of in-home parenting interventions to support cognition-enhancing parent-child interactions for 9 - 24 month old children (Walker et al., 2005), and full-day childcare center providing games for 3 - 5 year olds to improve EF found faster and greater cognitive development in the intervention groups with gains still evident when the children were 17 - 21 years old. Another 8-week RCT of a 2 times/week parenting skill and child EF training groups showed intervention-related enhancement of language function, social skills and ERP measures of attentionrelated brain function (Neville et al., 2013). A controlled study involving 759 children in 79 classrooms trained teachers to use special games and pedagogic techniques to enhance EF and found broad EF gains in children in low SES schools (Blair \& Raver, 2014). Studies in 500 to 1000 children of low-cost, easily scaled, web-based EF training games for classroom use found increases in EF (Kavanaugh et al., 2018) and far-transfer to improved performance on school-administered reading and math achievement tests (Wexler et al., 2016). As Luby wrote (Luby, 2015), "In developmental science and medicine, it is not often that aspects of a public health 
problem's etiology and solution become clearly elucidated. It is even less common that feasible and cost-effective solutions to such problems are discovered and within reach." Subsequent work, including that described in this report, provide additional support for these important but yet to be widely acted on assessments. There are neuroscience-informed, evidence-based interventions to address the urgent problems related to compromised neurocognitive development in children raised in poverty and/or exposed to violence. Application of these interventions in areas of poverty, violence and domestic instability could have positive public health outcomes on the same scale as vaccination against viral diseases.

Although we found grade-related growth of inhibition on the GNG test, scores were not significantly associated with SES or academic achievement. Best et al. (2011) argued that more complex tests of EF are more predictive of academic success, and the GNG measure of inhibition is less complex than the tests of attention and working memory used in the present study. Cheung et al. (2004) found that in young adults, inhibition as measured by a GNG test was not correlated with three other measures of inhibition or any other tests of EF, while two of the other tests of inhibition (the Competing Motor Program and Stop Signal Response Task) were correlated with each other and other tests of EF. Not surprisingly, then, past studies using different measures of inhibition have found varying degrees of association with academic achievement, and other studies using the GNG test also failed to find associations with academic achievement (Noble et al., 2007; Vandenbroucke \& Baeyens, 2017). While different tests of inhibition may relate to the same general construct, the nature and degree of cognitive demand for successful inhibition seems to be related to the context of other cognitive operations in which it is required, leading to different degrees of association between inhibition and other measures depending on the specific measure of inhibition.

\section{Limitations}

This study had the advantage of a large and heterogenous sample of children, but it was a convenience sample comprised of schools using the C8 Sciences program. At the individual level of 5717 children we are confident the sample is truly representative. At the school level, the sample was more limited; but the 40 schools were distributed in urban and rural areas across the United States representing a full SES range. While validity criteria were applied to tests, some valid data may have been excluded or some invalid data included. Motivation for performance was not directly observed, and it is a potential confound even in individual administration under optimal conditions. However, using embedded validity checks is consistent with other on-line testing systems which have been well-accepted by the professional community. In addition, there are other dimensions of EF that we did not test and which if included might increase the degree of mediation by EF. Finally, there are limitations inherent in the correlational foundation of all mediation analyses such that EF compromise could be a correlate of some other variable that is the real causal mediator of the effects of poverty on academic outcomes. Since we aggregated data at the school level, this other variable could be some characteristic of the schools. However, the mediation analysis tested specific a priori assumptions based on extensive existing research showing that EF is related to both poverty and academic outcomes. Moreover, interventions to increase EF have been shown in randomized controlled studies to increases academic outcomes in children raised in poverty. These prior findings greatly increase the likelihood that EF is itself the mediator rather than being a "stand-in" variable for some other factor not similarly recognized or targeted in past research. 


\section{Conclusion}

One set of previous research studies has established that executive functions predict academic, health and employment outcomes. Another set of studies has demonstrated that poverty compromises academic, health and employment outcomes. A third set of studies has shown that poverty compromises executive cognitive functions. This study provides more direct empirical support for the first time in a large and economically diverse population that poverty compromises academic outcomes by compromising executive function.

\section{Declaration of Interests}

Two of the authors, Professors Morris Bell and Bruce Wexler, have financial interest in the Yale start-up company C8 Sciences. A third author, Dr. Ahmet Esat Imal, is a part time employee of C8 Sciences. C8 Sciences have developed the assessments described in the paper, and an education intervention directed at improving cognitive skills and learning outcomes in children from poverty. The results presented in our manuscript support the value of the assessments done by C8 Sciences and the rationale for the C8 Sciences intervention. Because of this, Drs. Bell, Imal and Wexler could benefit financially from the publication of these findings. Pittman has no competing financial interest.

\section{References}

Amatullah; \& Setiawan, A.R.. (2017, October 10). Nadirsyah Hosen: berkarya sebagai diaspora. Majalah SANTRI, 7: 56-59 . URL:

https://issuu.com/majalahsantri/docs/santri_edisi_7/58

Koimah, Siti; \& Setiawan, A.R.. (2019, September 23). A Glance Overview of the Living Environment.

Setiawan, A.R.. (2015, November 03). Dibalik Nama Besar Albert Einstein: Dari Politik, Asmara, hingga Matematika. fisikanet.lipi.go.id. URL: http://www.fisikanet.lipi.go.id/utama.cgi?artikel\&1446556354\&2

Setiawan, A.R.. (2015, November 07). Dibalik Sampul Buku A Brief History of Time, agar pengetahuan tak hanya dinikmati ilmuwan. fisikanet.lipi.go.id. URL: http://www.fisikanet.lipi.go.id/utama.cgi?artikel\&1446855103\&2

Setiawan, A.R.. (2015, November 10). Kehidupan Asmara Hawking: raga lumpuh, jiwa masih bisa tersentuh. fisikanet.lipi.go.id. URL: http://www.fisikanet.lipi.go.id/utama.cgi?artikel\&1447145876\&2

Setiawan, A.R.. (2015, October 10). 10 Kejutan Subatomik. fisikanet.lipi.go.id. URL: http://www.fisikanet.lipi.go.id/utama.cgi?artikel\&1444577286\&3

Setiawan, A.R.. (2015, October 31). Kurir Mikroskopis Alam Semesta bukan debu biasa. fisikanet.lipi.go.id. URL:

http://www.fisikanet.lipi.go.id/utama.cgi?artikel\&1446304060\&2 
Setiawan, A.R.. (2017, February 24). Penerapan Pendekatan Saintifik untuk Melatihkan Literasi Saintifik dalam Domain Kompetensi pada Topik Gerak Lurus di Sekolah Menengah Pertama. Undergraduate Thesis. Bandung: Universitas Pendidikan Indonesia. URL: http://repository.upi.edu/29074/

Setiawan, A.R.. (2017, June 02). Aisha. qureta.com. URL: https://www.qureta.com/next/post/aisha-humaira

Setiawan, A.R.. (2017, June 03). Dari Yuli Hingga Julia. qureta.com. URL: https://www.qureta.com/next/post/dari-yuli-hingga-julia-2

Setiawan, A.R.. (2018, April 10). Busana: pemantas raga, pelaras jiwa. Majalah SANTRI, 8: 26-27. URL: https://issuu.com/majalahsantri/docs/majalah_santri_8/28

Setiawan, A.R.. (2018, April 10). Eny Rochmawati Octaviani: memberikan hiburan, menyuntikkan harapan. Majalah SANTRI, 8: 15-18. URL:

https://issuu.com/majalahsantri/docs/majalah_santri_8/17

Setiawan, A.R.. (2018, April 10). Rosa Amalia Iqony: paduan yakin diri dan rendah hati. Majalah SANTRI, 8: 46. URL:

https://issuu.com/majalahsantri/docs/majalah_santri_8/48

Setiawan, A.R.. (2018, December 18). Irma Rahma Suwarma. qureta.com. URL: https://www.qureta.com/next/post/irma-rahma-suwarma

Setiawan, A.R.. (2018, July 03). Tangis Daniela Hantuchová. qureta.com. URL: https://www.qureta.com/next/post/tangis-daniela-hantuchova

Setiawan, A.R.. (2018, July 16). Rustriningsih, Srikandi Tersisih. qureta.com. URL: https://www.qureta.com/next/post/rustriningsih-srikandi-tersisih

Setiawan, A.R.. (2018, June 27). Ice. qureta.com. URL:

https://www.qureta.com/next/post/ice

Setiawan, A.R.. (2018, June 28). Dewi Perssik. qureta.com. URL: https://www.qureta.com/next/post/dewi-perssik

Setiawan, A.R.. (2018, March 06). Breast Capital. qureta.com. URL: https://www.qureta.com/next/post/breast-capital

Setiawan, A.R.. (2018, March 06). Menyoal Vokal Duo Serigala. qureta.com. URL: https://www.qureta.com/next/post/menyoal-vokal-duo-serigala

Setiawan, A.R.. (2018, March 07). Mengenal Oza Kioza. qureta.com. URL: https://www.qureta.com/next/post/mengenal-oza-kioza

Setiawan, A.R.. (2018, March 09). Asal Usul Nama Via Vallen. qureta.com. URL: https://www.qureta.com/next/post/asal-usul-nama-via-vallen

Setiawan, A.R.. (2018, March 09). Kepedulian Airin Rachmi Diany pada Pendidikan. qureta.com. URL: https://www.qureta.com/next/post/kepedulian-airin-rachmidiany-pada-pendidikan 
Setiawan, A.R.. (2018, March 09). Ketika YoonA Menyaksikan Real Madrid Menghempaskan PSG. qureta.com. URL: https://www.qureta.com/next/post/ketikayoona-menyaksikan-real-madrid-menghempaskan-psg

Setiawan, A.R.. (2018, March 09). Laila Fariha Zein (a.k.a. Uus atau Febi). qureta.com. URL: https://www.qureta.com/next/post/laila-fariha-zein-febi

Setiawan, A.R.. (2018, March 09). Pantat Perekat Umat. qureta.com. URL: https://www.qureta.com/next/post/pantat-perekat-umat

Setiawan, A.R.. (2018, March 09). Sisi Religi Grace Natalie. qureta.com. URL: https://www.qureta.com/next/post/sisi-religi-grace-natalie

Setiawan, A.R.. (2018, March 10). Venice Min. qureta.com. URL: https://www.qureta.com/next/post/venice-min

Setiawan, A.R.. (2018, March 11). Kisah Kasih Ayah di Balik Mata Najwa. qureta.com. URL: https://www.qureta.com/next/post/kisah-kasih-ayah-di-balikmata-najwa

Setiawan, A.R.. (2018, March 11). Rosa Amalia Iqony. qureta.com. URL: https://www.qureta.com/next/post/rosa-amalia-iqony

Setiawan, A.R.. (2018, March 12). Clara Ng. qureta.com. URL: https://www.qureta.com/next/post/clara-ng

Setiawan, A.R.. (2018, March 14). Meniti Ilmuwati. qureta.com. URL: https://www.qureta.com/next/post/meniti-ilmuwati

Setiawan, A.R.. (2018, March 14). Surely You're Joking, Mrs. Ilmy!. qureta.com. URL: https://www.qureta.com/next/post/surely-you-re-joking-mrs-ilmy

Setiawan, A.R.. (2018, March 15). Eny R. Octaviani. qureta.com. URL: https://www.qureta.com/next/post/eny-r-octaviani

Setiawan, A.R.. (2018, March 17). Maryam Musfiroh: An Educator for Our Time. qureta.com. URL: https://www.qureta.com/next/post/maryam-musfiroh-aneducator-for-our-time

Setiawan, A.R.. (2018, March 19). Airin Rachmi Diany, Lilin Penerang Masyarakat Urban. qureta.com. URL: https://www.qureta.com/next/post/airin-rachmi-dianylilin-penerang-masyarakat-urban

Setiawan, A.R.. (2018, March 19). Guru yang Menyapih: Catatan Perjalanan Pribadi Nong Darol Mahmada. qureta.com. URL: https://www.qureta.com/next/post/guruyang-menyapih-catatan-perjalanan-pribadi-nong-darol-mahmada

Setiawan, A.R.. (2018, March 19). Kamu dalam Aku: A Brief Story of Park Bom. qureta.com. URL: https://www.qureta.com/next/post/kamu-dalam-aku-a-briefstory-of-park-bom 
Setiawan, A.R.. (2018, March 21). Bidadari di Kesunyian itu Bernama Maria Sharapova. qureta.com. URL: https://www.qureta.com/next/post/bidadari-dikesunyian-itu-bernama-maria-sharapova

Setiawan, A.R.. (2018, March 25). Novi Kaka: Sahabat, Panutan, Pembimbing. qureta.com. URL: https://www.qureta.com/next/post/novi-kaka-sahabat-panutanpembimbing

Setiawan, A.R.. (2018, May 24). Fakhrun. qureta.com. URL: https://www.qureta.com/next/post/fakhrun

Setiawan, A.R.. (2018, November 24). Penerapan Pendekatan Saintifik untuk Melatih Literasi Saintifik dalam Domain Kompetensi pada Topik Gerak Lurus di Sekolah Menengah Pertama. Seminar Nasional Fisika ke-4 (SiNaFi IV), Universitas Pendidikan Indonesia (UPI). DOI: https://dx.doi.org/10.13140/RG.2.2.23154.04809

Setiawan, A.R.. (2018, October 05). Karen Armstrong. qureta.com. URL: https://www.qureta.com/next/post/karen-armstrong

Setiawan, A.R.. (2018, September 17). Lola Zieta Azelien. qureta.com. URL: https://www.qureta.com/next/post/lola-zieta-azelien

Setiawan, A.R.. (2019, August 21). Penyusunan Program Pembelajaran Biologi Berorientasi Literasi Saintifik. Seminar Nasional Sains \& Entrepreneurship VI (SNSE VI), Universitas PGRI Semarang (UPGRIS). DOI: https://dx.doi.org/10.13140/RG.2.2.13716.86400

Setiawan, A.R.. (2019, December 20). Literasi Saintifik Berdasarkan Kecerdasan Majemuk dan Motivasi Belajar. Media Penelitian Pendidikan: Jurnal Penelitian dalam Bidang Pendidikan dan Pengajaran, 13(02): 126-137. DOI: http://dx.doi.org/10.26877/mpp.v13i2.4913

Setiawan, A.R.. (2019, December 23). Contoh Langkah Pembelajaran Berorientasi Literasi Saintifik. santrimilenial.net. URL: https://santrimilenial.net/contoh-langkahpembelajaran-berorientasi-literasi-saintifik/

Setiawan, A.R.. (2019, December 30). Instrumen Penilaian Pembelajaran Fiqh Mu'āmalāt Berorientasi Literasi Finansial. Eklektik: Jurnal Pendidikan Ekonomi dan Kewirausahaan, 02(02): 258-272. DOI: http://dx.doi.org/10.24014/ekl.v2i2.8117

Setiawan, A.R.. (2019, June 14). Deasy Noviyanti, Perempuan Berbadan Defisit Lemak. qureta.com. URL: https://www.qureta.com/next/post/deasy-noviyantiperempuan-berbadan-defisit-lemak

Setiawan, A.R.. (2019, June 26). Peningkatan Literasi Saintifik melalui Pembelajaran Biologi Menggunakan Pendekatan Saintifik. Journal of Biology Education, 02(01): 223-235. URL: http://journal.stainkudus.ac.id/index.php/jbe/article/view/5278

Setiawan, A.R.. (2019, March 23). Penerapan Pendekatan Saintifik dalam Pembelajaran Biologi sebagai Upaya Melatih Literasi Saintifik Siswa Sekolah Menengah. Seminar Nasional Biologi 2019 Inovasi Penelitian dan Pembelajaran Biologi III (IP2B III), Universitas Negeri Surabaya (UNESA). DOI: https://dx.doi.org/10.13140/RG.2.2.19798.60484 
Setiawan, A.R.. (2019, March 23). Penggunaan Naḍom Mabāili' 'Asyroh dalam Pembelajaran Biologi untuk Meningkatkan Motivasi dan Hasil Belajar. Seminar Nasional Biologi 2019 Inovasi Penelitian dan Pembelajaran Biologi III (IP2B III), Universitas Negeri Surabaya (UNESA). DOI:

https://dx.doi.org/10.13140/RG.2.2.33220.37763

Setiawan, A.R.. (2019, March 23). Upaya Meningkatkan Motivasi Belajar dalam Pembelajaran Ilmu Pengetahuan Alam (IPA) Melalui Bacaan Populer. Seminar Nasional Biologi 2019 Inovasi Penelitian dan Pembelajaran Biologi III (IP2B III), Universitas Negeri Surabaya (UNESA). DOI:

https://dx.doi.org/10.13140/RG.2.2.13087.71847

Setiawan, A.R.. (2019, May 07). Penerapan Pendekatan Saintifik untuk Melatih Literasi Saintifik dalam Domain Kompetensi pada Topik Gerak Lurus di Sekolah Menengah Pertama. Prosiding Seminar Nasional Fisika (SiNaFi) 2018: 7-13. URL: http://proceedings.upi.edu/index.php/sinafi/article/view/355

Setiawan, A.R.. (2019, November 23). Analisis Keabsahan dan Keandalan Science Motivation Questionnaire II (SMQ II) Versi Bahasa Indonesia. Seminar Nasional Fisika V (SiNaFi 5.0), Universitas Pendidikan Indonesia (UPI). DOI: https://doi.org/10.31237/osf.io/6zeph

Setiawan, A.R.. (2019, November 23). Menyusun Instrumen Penilaian untuk Pembelajaran Topik Lingkungan Berorientasi Literasi Saintifik. Seminar Nasional Fisika V (SiNaFi 5.0), Universitas Pendidikan Indonesia (UPI). DOI: https://dx.doi.org/10.35542/osf.io/sc6d2

Setiawan, A.R.. (2019, November 23). Profil Literasi Saintifik Berdasarkan Kecerdasan Majemuk dan Motivasi Belajar. Seminar Nasional Fisika V (SiNaFi 5.0), Universitas Pendidikan Indonesia (UPI). DOI:

https://dx.doi.org/10.35542/osf.io/m7n95

Setiawan, A.R.. (2019, October 02). Efektivitas Pembelajaran Biologi Berorientasi Literasi Saintifik. Thabiea : Journal of Natural Science Teaching, 02 (02): 83-94. DOI: http://dx.doi.org/10.21043/thabiea.v2i2.5345

Setiawan, A.R.. (2019, October 05). Menyusun Instrumen Penilaian untuk Pembelajaran Ekologi Berorientasi Literasi Saintifik. Seminar Nasional \& Workshop Biologi, IPA, dan Pembelajarannya ke-4 (SnoWBel IV), Universitas Negeri Malang (UM). DOI: https://dx.doi.org/10.13140/RG.2.2.21931.39206

Setiawan, A.R.. (2019, October 14). Penyusunan Program Pembelajaran Biologi Berorientasi Literasi Saintifik. Seminar Nasional Sains \& Entrepreneurship VI (SNSE VI): 255-1-8. URL: http://conference.upgris.ac.id/index.php/snse/article/view/255

Setiawan, A.R.. (2019, September 11). Designing a Test of Scientific Literacy Competences for Elementary Education.

Setiawan, A.R.. (2019, September 28). Aligning Education for Sustainable Development (ESD) and Traditional Islamic Perspective. 
Setiawan, A.R.. (2019, September 30). Instrumen Penilaian untuk Pembelajaran Ekologi Berorientasi Literasi Saintifik. Assimilation: Indonesian Journal of Biology Education, 02(02): 42-46. DOI: https://dx.doi.org/10.17509/aijbe.v2i2.19250

Setiawan, A.R.. (2020, April 01). Sharifah Halimah Alaydrus. Thesis Commons. DOI: https://dx.doi.org/10.31237/osf.io/fp79c

Setiawan, A.R.. (2020, April 02). Desain Pembelajaran untuk Membimbing Siswa Sekolah Dasar dalam Memperoleh Literasi Saintifik. EdArXiv. DOI:

https://dx.doi.org/10.35542/osf.io/u59f8

Setiawan, A.R.. (2020, February 18). Menyusun Instrumen Penilaian untuk Pembelajaran Topik Lingkungan Berorientasi Literasi Saintifik. Prosiding Seminar Nasional Fisika (SiNaFi) 2019: 15-21. URL:

http://proceedings.upi.edu/index.php/sinafi/article/view/563

Setiawan, A.R.. (2020, January 17). Penerapan Pendekatan Saintifik dalam Pembelajaran Biologi sebagai Upaya Melatih Literasi Saintifik. Prosiding Seminar Nasional Biologi 2019 Inovasi Penelitian dan Pembelajaran Biologi III (IP2B III): 140-145. URL:

http://semnasbiologi.conference.unesa.ac.id/ocs/index.php/semnasbio/IP2BIII/pape r/viewFile/6/19

Setiawan, A.R.. (2020, January 17). Penggunaan Mabadi 'Asyroh dalam Pembelajaran Biologi untuk Meningkatkan Motivasi dan Hasil Belajar. Prosiding Seminar Nasional Biologi 2019 Inovasi Penelitian dan Pembelajaran Biologi III (IP2B III): 158-164. URL:

http://semnasbiologi.conference.unesa.ac.id/ocs/index.php/semnasbio/IP2BIII/pape r/viewFile/11/21

Setiawan, A.R.. (2020, January 17). Upaya Meningkatkan Motivasi Belajar dalam Pembelajaran Ilmu Pengetahuan Alam (IPA) Melalui Bacaan Populer. Prosiding Seminar Nasional Biologi 2019 Inovasi Penelitian dan Pembelajaran Biologi III (IP2B III): 154-157. URL:

http://semnasbiologi.conference.unesa.ac.id/ocs/index.php/semnasbio/IP2BIII/pape r/viewFile/5/51

Setiawan, A.R.. (2020, January 24). Pembelajaran Tematik Berorientasi Literasi Saintifik. Jurnal Basicedu: Journal of Elementary Education, 04(01): 71-80. URL: https://jbasic.org/index.php/basicedu/article/view/298

Setiawan, A.R.. (2020, March 01). Pendidikan Literasi Finansial Melalui Pembelajaran Fiqh Mu'āmalāt Berbasis Kitab Kuning. Nazhruna: Jurnal Pendidikan Islam, 03(01): 138-159. URL: http://e-journal.ikhac.ac.id/index.php/NAZHRUNA/article/view/522

Setiawan, A.R.. (2020, March 22). JUPE My Uncut Story. Open Science Framework (OSF). DOI: https://dx.doi.org/10.31219/osf.io/qdxga

Setiawan, A.R.. (2020, March 23). What is the Best Way to Analyze Pre-Post Data?. EdArXiv. DOI: https://dx.doi.org/10.35542/osf.io/h4e6q

Setiawan, A.R.; \& Koimah, Siti. (2019, September 23). Effective Learning and Teaching. 
Setiawan, A.R.; \& Saputri, Wahyu Eka. (2019, November 13). Analysis on Validity and Reliability of Science Motivation Questionnaire II (SMQ-II) Bahasa Indonesia Version.

Setiawan, A.R.; Mufassaroh, Arij Zulfi. (2019, June 28). Menyusun Soal Literasi Saintifik untuk Pembelajaran Biologi Topik Plantae dan Animalia. BIOSFER: Jurnal Biologi dan Pendidikan Biologi, 04(01): 33-40. URL: http://dx.doi.org/10.23969/biosfer.v4i1.1484

Setiawan, A.R.; Puspaningrum, Mita; \& Umam, Khoirul. (2019, December 06). Pembelajaran Fiqh Mu'āmalāt Berorientasi Literasi Finansial. Tarbawy: Indonesian Journal of Islamic Education, 06(02): 187-102. URL:

https://ejournal.upi.edu/index.php/tarbawy/article/view/20887

Setiawan, A.R.; Utari, Setiya; Nugraha, Muhamad Gina. (2016, December 17). Mengonstruksi Rancangan Soal Domain Kompetensi Literasi Saintifik Siswa SMP Kelas VIII pada Topik Gerak Lurus. Seminar Nasional Fisika ke-2 (SiNaFi II), Universitas Pendidikan Indonesia (UPI). DOI:

https://dx.doi.org/10.13140/RG.2.2.31856.10246/1

Setiawan, A.R.; Utari, Setiya; Nugraha, Muhamad Gina. (2017, September 22). Mengonstruksi Rancangan Soal Domain Kompetensi Literasi Saintifik Siswa SMP Kelas VIII pada Topik Gerak Lurus. Wahana Pendidikan Fisika, 02(02): 44-48. URL: https://ejournal.upi.edu/index.php/WPF/article/view/8277/0

Setiawan; Adib Rifqi; \& Van Bee, Jeffa Lianto. (2019, October 01). Sekilas tentang Etnomatematika. ResearchGate.net. URL:

https://www.researchgate.net/publication/336206880_Sekilas_tentang_Etnomatem atika

Siayah, Syarofis; \& Setiawan, A.R.. (2019, June 26). Multiple Intelligences Survey: Analysis on Validity and Reliability of Bahasa Indonesia Version Through Different Education Level.

Siayah, Syarofis; Kurniawati, Novi Khoirunnisa; \& Setiawan, A.R.. (2020, February 29). Six Main Principles for Quality Learning based on "Ta'līm al-Muta'allim Ṭorīq alTa'allum". ResearchGate.net. DOI:

https://dx.doi.org/10.13140/RG.2.2.32361.65127

Siayah, Syarofis; Kurniawati, Novi Khoirunnisa; Velasufah, Whasfi; Setiawan, A.R.. (2019, September 30). A Brief Explanation of Basic Science Education.

ResearchGate.net. URL:

https://www.researchgate.net/publication/339385375_A_Brief_Explanation_of_Basic _Science_Education

Velasufah, Whasfi; \& Setiawan, A.R.. (2019, August 09). Science Motivation Questionnaire II (SMQ-II): Analysis on Validity and Reliability of Bahasa Indonesia Version Through Various Learning Context. 